Etnográfica

Revista do Centro em Rede de Investigação em

Antropologia

vol. 23 (1) | 2019

Vol. $23(1)$

\title{
Political and social protests from the margins: the role of Mizrahi Jews in Israeli grassroots activism
}

Protestos políticos e sociais nos contextos de marginalidade: o papel dos judeus mizrahim no ativismo de base israelita

\section{Giulia Daniele}

\section{(2) OpenEdition}

Journals

Electronic version

URL: https://journals.openedition.org/etnografica/6506

DOI: $10.4000 /$ etnografica.6506

ISSN: 2182-2891

\section{Publisher}

Centro em Rede de Investigação em Antropologia

\section{Printed version}

Date of publication: 1 February 2019

Number of pages: $201-220$

ISSN: 0873-6561

\section{Electronic reference}

Giulia Daniele, "Political and social protests from the margins: the role of Mizrahi Jews in Israeli grassroots activism", Etnográfica [Online], vol. 23 (1) | 2019, Online since 24 March 2019, connection on 20 January 2022. URL: http://journals.openedition.org/etnografica/6506 ; DOI: https://doi.org/ 10.4000/etnografica.6506

\section{c) (i) (9)}

Etnográfica is licensed under a Creative Commons Attribution-NonCommercial 4.0 International License. 


\section{Political and social protests from the margins: the role of Mizrahi Jews in Israeli grassroots activism}

\section{Giulia Daniele}

This paper deals with the role of the most marginalized communities in social and political grassroots activism inside Israel, by focussing on the demanding issue that affects the combination of asymmetric relationships, internal discriminations and increasing inequalities within political protests. In detail, I analyse the involvement of social and political activists struggling to improve the rights of and in solidarity with Mizrahi Jews who have experienced different kinds of discrimination in Israeli society, but also in a few Israeli peace-oriented and leftist contexts. Such heterogeneity of Israeli Jewish political and social grassroots organisations and the crucial role of Mizrahi Jewish activists can be considered as a challenging field of study needing to be analysed and related to the main subject matters concerning the Israeli current status quo.

KEYWORDS: Israel, Mizrahi Jews, grassroots activism, marginalization, socio-political struggles.

Protestos políticos e sociais nos contextos de marginalidade: o papel dos judeus mizrahim no ativismo de base israelita - Este artigo aborda o papel das comunidades mais marginalizadas no contexto do ativismo social e político de base em Israel, focando-se de forma crítica na combinação entre relações assimétricas, discriminações internas e desigualdades crescentes nos protestos políticos. Mais concretamente, é analisada a participação dos ativistas sociais e políticos que lutam para melhorar os direitos e em solidariedade com os judeus mizrahim, que têm sofrido diferentes tipos de discriminação na sociedade israelita, mas também em contextos pacifistas ou ao nível da esquerda israelita. A heterogeneidade das organizações políticas e sociais de base israelitas, a par do papel crucial dos ativistas judeus mizrahim, pode constituir um campo de análise muito desafiante, ao ir ao encontro das principais questões relativas ao atual status quo em Israel.

PALAVRAS-CHAVE: Israel, judeus mizrahim, ativismo de base, marginalização, lutas sócio-políticas.

DANIELE, Giulia (Giulia.Daniele@iscte-iul.pt) - ISCTE - Instituto Universitário de Lisboa, Centro de Estudos Internacionais (CEI-IUL), Portugal. 


\section{INTRODUCTION}

Historically, internal struggles in the state of Israel have been significant and very different, though often unmentioned by the media and mainstream politics. The challenges posed by Israel's most marginalized communities, such as Palestinian citizens of Israel, Bedouins, Mizrahi Jews, Ethiopian Jews and, more recently, African refugees, have intensified throughout the country's history. ${ }^{1}$ The causes and consequences of these protests have been related to the discriminatory nature of the Israeli state, and in particular to its settler colonial structure (Veracini 2006; Wolfe 1999), which has restricted these marginalized communities to specific geographical, socio-economic and political spaces in Israel.

This paper analyses different political initiatives that have been used by Mizrahi Jews to protest against the government's hegemonic policies and to question the Ashkenazi leadership which dominates every area of daily Israeli life, from politics to the media, from the economy to culture. These struggles have included demonstrations, rallies, strikes and public campaigns against the status quo. This status quo is founded on power asymmetries among Israeli citizens, and specifically between the Ashkenazi minority elite and the rest of the population. Although these people represent the majority in the country, they have mainly been considered deprived ethnic minorities. Interconnecting struggles are mostly based on ethnic and class claims. The study of the role of Mizrahim in different forms of socio-political protests is of critical importance for an understanding of the current reality of Israeli society, namely an increasingly fragmented society in which public policies are used to increase internal discrimination.

Considering the peculiarity of such context, the paper also takes into account previous academic studies that question the classical notion of segmentarity in different ethnographic backgrounds. ${ }^{2}$ In particular, the concept of "ethnic

I Before elaborating on the core issue of this paper, it is important to clarify the ethno-national/ class composition of Israeli society that has deepened intergroup disparities and inequalities. At the top of society, Ashkenazi Jews coming mainly from Europe and North America represent the power elite. They are followed by the Mizrahi Jews, also known as "Orientals" or "Sephardi," who have their origins in Arab and Muslim countries and form the majority of the Israeli population. Going down to the bottom, Palestinian citizens of Israel represent 20 per cent of the population and are usually defined as "second-class" citizens, or even "third-class," if the Mizrahim are themselves considered "second-class." In addition to the three main components of Israeli society, other marginalized and discriminated communities are Ethiopian Jews, Bedouins, migrant workers and African refugees. Although this is not a well-known fact, the vast majority of world Jewry (about 85 per cent) is Ashkenazi but only a small minority lives in the state of Israel, while the rest is Mizrahi but resides mainly in Israel (Swirski 1989).

2 See in detail Michael Herzfeld (1997) in relation to Southern Europe and John Galaty (1982) concerning the Eastern Africa background. 
shifters" (Galaty 1982) can be translated into the specific case study of Mizrahi Jews and the ways of constructing their Jewishness, namely regarding being part of the Israeli Jewish society, while continuing to be excluded from its major positions and power and, at the same time, representing fragmented identities within their own community. In this frame, the ethnic label has a deep impact on everyday life as well as on socio-political activism within Israel, especially in relation to the heterogeneity of being and expressing diverse forms of Jewishness.

Researching one of the most marginalized and excluded communities in Israel means dealing with deep-seated ethno-national narrative identities. This may involve ethical and moral dilemmas in the research itself, and in the researcher's stance and reflexivity. ${ }^{3}$ In addition, this type of theoretical contribution can also help to challenge the status quo and address social and political constructions that are taken for granted by the majority of people involved. Given the gap in the literature on these issues, it is now crucial to consider the complexity of differences and inequalities in Israeli society and conduct research on people who would otherwise have no voice. Moreover, this topic has recently been highly politicised and is now being discussed publicly in a number of campaigns. These campaigns are mainly associated with the revival of Mizrahi culture by the establishment of the Biton Committee, and the disappearance of hundreds of Yemenite children in the 1950s.

Since the establishment of the state of Israel, Jews who emigrated to Israel from the Arab and Muslim world have represented the most marginalized ethno-classes in Israeli Jewish society and have been relegated to peripheral areas of the new country. The so-called Ma'abarot were first set up as canvas immigrant camps and then replaced by transit camps composed of temporary corrugated metal dwellings and "development towns."4 They were a way of placing the Mizrahi people in a subordinate position in relation to Ashkenazi power. At the same time, they served to "Judaise" Israel by settling peripheral

3 Accessing a research field is often a complex process, especially if the subjects belong to a marginalized, disadvantaged group. In particular, it is necessary to reflect carefully on the researchers' representations of these groups, along with the direct implications that the research has for them. About this theoretical and methodological debate see, among others, Researching Marginalized Groups (Bhopal and Deuchar 2016) and Decolonizing Methodologies: Research and Indigenous People (Smith 1999).

4 This type of urban project has been one of the main tools used by the Jewish state to also create a Jewish majority in Galilee and the Negev Desert. With no other choice, Mizrahi immigrants were settled in these development towns, where it was clear from the start that they suffered political and cultural marginalization and substantial economic disadvantages. The intra-Jewish plan has always been evident. The dominant group, the Ashkenazim, would control the territory and dominate all sectors of society, while the Mizrahim would be forced into poor peripheral areas (Tzfadia and Yiftachel 2003). 
development towns on confiscated Palestinian Arab land, in order to increase hostility between the Mizrahim and Palestinians (Yiftachel 2000: 428).

In this framework, the way of defining this segment of the Israeli Jewish population has been somewhat controversial. Firstly, they were referred to as "Eastern" or "Oriental" Jews, who had been part of Middle Eastern and North African history for more than 2,500 years. Later, in the mid-1990s, the term Mizrahi became well known to the Israeli public when a few Mizrahi scholars started using it to broadcast their identity politics. Although this dissemination took place mostly in Ashkenazi-controlled media (Lavie 2014: 3), it was used in a number of contexts. For example, it was employed as a derogatory term to describe poorly educated, non-European Jews with few economic resources and as a self-definition especially by Mizrahi activists who wanted to re-claim their Arab origins in order to resist the Ashkenazi hegemony. Furthermore, many of them wanted to draw attention to the fact that they were integrated in Arab countries, where being Jewish and practising Judaism were regularly accepted.

In this context, Mizrahi political mobilisation has emerged as a reaction to the increase in their marginalization and deprivation in a reality based almost entirely on Ashkenazi history, culture and norms (Shohat 1988). Challenging mobilisation patterns based on heterogeneous narrative identities related in turn to different socio-economic conditions, political perspectives and ethnic belonging have increasingly raised self-awareness among the Mizrahim as to how to combat the Ashkenazi hegemony. From public housing to culture and heritage issues, from working-class to ethno-class demands, Mizrahi grassroots activism has supported a variety of struggles with a common aim: to overcome their socioeconomic, political and cultural marginality in Israeli society.

To understand the complexity and internal heterogeneity of the Mizrahi issue, generally known as the "Mizrahi struggle," it is necessary to take account of the different forms of resistance used by the Mizrahim against the Ashkenazi power. Based on my findings from fieldwork in Israel in the summer of 2016, this paper analyses the ongoing debate among Mizrahi grassroots activists who have developed strategies and called attention to different issues. In such a specific case study, political mobilisations need to be strictly linked to the Mizrahi identity as one that is collective but composed of many nuances. Although the Mizrahi people has often been described as a unique player in Israeli Jewish society in contrast with the Ashkenazim, they represent a variety of narrative identities, social structures, political memberships and cultural and religious belongings that are central to an examination of their role in the current reality in Israel. 
AN ONGOING TRADITION OF GRASSROOTS ACTIVISM: THE BEGINNING OF THE MIZRAHI STRUGGLE

What has been defined as the "Mizrahi issue" includes a number of historical, political, cultural and social initiatives from a variety of backgrounds and perspectives. Starting with the rejection of Ashkenazi society and its dominant discrimination against the Mizrahi people, a number of groups and movements have attempted to build up alternative politics aimed at rediscovering their Mizrahi origins and ceasing to imitate the Ashkenazi elites as the only way of being accepted into Israeli society. Against this background, the few Israeli Jewish scholars who have dealt with the relationship of oppression, discrimination and alienation between Ashkenazim and Mizrahim have contributed to the debate from several approaches. ${ }^{5}$ They are founded on the fact that these gaps within the Israeli Jewish population are embedded in socio-economic inequalities and are consequences of the way in which Ashkenazi Jews have maintained their privileged conditions at the expense of Mizrahi Jews.

Over the last 50 years, the agenda of these social and political mobilisations has been predominately class-oriented. This means that has been based on social justice and equality so as to go beyond a large inferiority complex experienced by many Mizrahim. Exclusion, marginalization and exploitation have been at the core of their struggles against the socioeconomic and political status of the majority of Mizrahi people. The asymmetry between Ashkenazim and Mizrahim has surrounded every aspect of daily life, especially in the poorest neighbourhoods and development towns, and second-generation Mizrahi activists started emerging in the early 1970s. In particular, two main historic forms of grassroots activism need to be analysed if we are to understand the current reality of the Mizrahi struggle. These are the Black Panthers and the Tent Movement.

Both sprang up in the 1970s and 1980s in the most impoverished neighbourhoods of Jerusalem that were inhabited by a large number of Mizrahi Jews. In spite of their rather different political projects, they have been considered the two main examples of Mizrahi grassroots activism. The Tent Movement has also been defined as an "urban social movement"

5 Among the most important and challenging Israeli studies working on the "Mizrahi issue," see Shlomo Swirski and Deborah Bernstein (Swirski 1989; Bernstein and Swirski 1982), who analysed the ethno-class division of labour inside Israel; Sami Shalom Chetrit (2009), who focused on the intra-Jewish conflict between White Jews-Ashkenazim and Black Jews-Mizrahim; Ella Shohat (2006), who questioned the denial of Arab Jewish voices both in the Middle-Eastern and in the North-American contexts from a cultural studies perspective; and Smadar Lavie (2014) who concentrated on the connection between gender, race and bureaucracy in Israel by analysing the specific case of Mizrahi single mothers. 
(Hasson 1993). They represented highly comprehensive criticism of the urban socio-political status and problems related to education, housing and public services. Not only did they address local issues, but in a few cases they also attempted to expand their struggle to a macro level through universal perspectives. As their political relevance was founded on fighting against ethnic disparities and social class asymmetries, their protests tended to include heterogeneous groups of people representing workers, students and new mostly North African - immigrants, i.e. in general terms, lower, marginalized communities.

In the early 1970s, one of the first movements that appeared on the public scene was the Israeli Black Panthers (HaPanterim or HaShhorim, in Hebrew). It was formed by second-generation Jewish immigrants living in a former Arab neighbourhood in Jerusalem, which was populated by Mizrahi Jews, especially from Morocco, called Musrara. They started as a protest movement characterised by a series of large demonstrations that took tens of thousands of people to the streets. In a few years the movement became more structured and developed a political programme that allowed them to participate in the Histadrut (the Israeli National Workers' Union) and the Knesset elections in September 1973 (Cohen and Shemesh 1976).

Their political agenda was focused on social and economic problems arising from discrimination against the Mizrahi community, especially in terms of housing, employment and education. In opposition to the idea that Israeli Jewish society's priority should be security in the country and the region, the Black Panthers called for fair distribution of public resources to all citizens, but particularly to the most underprivileged communities (not only the Mizrahim, but also Palestinians). Indeed, the movement was the first political player in Israel that also worked on behalf of the Palestinians and not only on an Oriental-ethnic level. This view included every untold story, every story of oppression. When leading figures and supporters of the Black Panthers talked about their struggle, they also talked about the black minority in the United States, apartheid in South Africa and the Palestinian struggle that they described as even harder than that of the Mizrahim [Abergel, author's interview, 2016]. Recognition of the Palestinian cause was one of the first attempts among these Israeli Jews to associate discrimination and racism against the Mizrahim with the military occupation of Palestinian territories (Ghanem 2010: 70).

Also defined as the "great black hope" of the Left in Israel (Greenstein 2014: 189), the promised uprising of the Mizrahi Jewish proletariat sparked great expectations, though these struggles failed to occur. On the contrary, the majority of the Mizrahim have continued to follow the exclusionary nationalism led by the right-wing parties and generally supported by most of the Israeli Jewish population. A number of reasons have prevented the 
movement from becoming the recognised representative of the Mizrahim, as explained by Reuven Abergel, one of the founders and former leader of the Black Panthers:

"The political system does not allow the Mizrahi issue to come out. The Mizrahim are stuck in this situation. They are oppressed and still believe they are part of the system and the government. This is why if the Mizrahi people want to join in, they try to push them out. It's a little bit like an incestuous relationship. We, the Black Panthers, more than 40 years ago, made the effort to bring them out. We met the Black Panthers in America and the Palestinians in Europe. We tried to talk with journalists there. Our problem was that our communications were limited as we knew only Hebrew and have no command of other languages like the Ashkenazim do. The other obstacle is that we are poor. We do not have organisational skills like the human rights organisations and the way in which the Ashkenazim get money from them" [Abergel, author's interview, 2016].

Nevertheless, the Black Panthers were crucial players in Israeli politics as they triggered a political process that allowed other grassroots protest movements to appear in the early 1980s and fight especially against local housing conditions in much marginalized neighbourhoods, such as Katamon, Musrara, and Ir Ganim. One of these other organisations, the Tent Movement (Ohalim, in Hebrew), was a sort of umbrella for local neighbourhood groups, such as community workers, university students and theatre actors, in the area of Jerusalem. It created its first unit, called Ohel Joseph, during the 1973 Yom Kippur War to improve everyday living conditions for their community. Unlike the Black Panthers, the Tent Movement identified more with local issues through a very strong link between sense of identity and locality. Despite this deeper connection with the specific interests of their local communities, they followed in the footsteps of the Black Panthers. In other words, they tried to extend the marginalized Mizrahi situation to Israeli society as a whole.

While politically speaking the movement also had relationships with the Likud, given the predominant residents' right-wing orientation, they stood clearly against government investments in settlements in the occupied Palestinian territories, rather than in the poorest neighbourhoods and development towns (Ghanem 2010: 71). On the other hand, their main expectations were dampened by feelings of deprivation and frustration. These were common features of such movements founded by second-generation Mizrahi youth that, in spite of attempting to play an active role in Israeli society, has continued to suffer socio-economic restrictions, such as inappropriate housing and a lack of educational services (Hasson 1993: 42-43). 
MOST RECENT MIZRAHI INITIATIVES

AND THEIR MAIN ISSUES

In the 1990s, further struggles for public housing and better social cohesion in the most underprivileged neighbourhoods took place as one of the main responses to the deep transformation of Israeli society into a globalised neoliberal system. They included another kind of "tent movement" led mostly by women who decided to organise encampments from town to town in reaction to the flood of tens of thousands of immigrants from the former Soviet Union. These immigrants were generously subsidised by the Israeli government to the detriment of the Jewish lower classes, mainly composed of Mizrahi Jews. In particular, in the last 30 years, protests calling for public housing solutions have been undertaken by Mizrahi single mothers, who represent one of the most disadvantaged segments in Israeli society due to a racist political economy (Lavie 2014).

Local traditions of encampments in the poorest neighbourhoods mostly populated by Mizrahim have sprung up all over the country. For example, in HaTikva, a neighbourhood in Tel Aviv, at the beginning of every summer since the early 1990s, families from the area have decided to camp in the public park to demand social housing plans. This is a standardised process happening every year and they have usually been removed by the police, in line with the rigid policy of the local municipality, which has tried to reduce and discourage this kind of protest (Leibner 2015). Although in different ways, with different goals and with the support of different political actors, similar "tent movements" have become a common form of struggle in the history of grassroots movements in Israel. The most recent examples happened in the summer of $2011 .^{6}$

As a result of a considerable increase in neoliberal processes and specific Israeli policy on the military occupation of Palestinian territories and the establishment of new illegal settlements, in general terms public housing and rent subsidies have fallen by the wayside. This has made socio-economic polarisation one of the main internal difficulties that has remained unaddressed by the political agenda of the majority of Israeli governments and parties. These circumstances have helped to divide the main Israeli cities into ethnicand class-separated neighbourhoods. This socio-political division has created neighbourhoods inhabited mostly by upper- and middle-class Ashkenazi Jews,

6 This different set of priorities and actors involved in "tent movements" inside Israel was clear in July 2011 when the main protest was started in central Tel Aviv by middle-class Ashkenazi students who were mostly interested in obtaining affordable housing and policies to "improve" neighbourhoods by excluding the poorest, while in other underprivileged areas inhabited by the most marginalized communities people demanded public housing policies. 
on the one hand, and impoverished neighbourhoods populated mostly by lower-class Mizrahi Jews, on the other. ${ }^{7}$

Since the 1990s, other examples of Mizrahi grassroots activism have become relevant in different spheres. They are still important today, in particular in their struggle for social and cultural rights in a multiethnic and multicultural society. One of them is the Mizrahi Democratic Rainbow Coalition (Hakeshet HaDemocratit HaMizrahit, in Hebrew), also known as the Keshet, that was set up by second- and third-generation Mizrahi intellectuals as an apolitical, nonparliamentary social movement. Its aim has been to suggest a new political agenda in Israel, founded on universal beliefs of equality among citizens and the specificity of the Mizrahi struggle. An ongoing balance, which in several cases has also become an ongoing dilemma between universalism and particularism, has been the main characteristic of the movement. From this perspective, starting to address the peculiarity of Mizrahi exclusion and discrimination in Israeli society would have allowed them to achieve universal results (Abu 2011: 111-112). As expressed in depth by the current spokeswoman of the Keshet, Sigal Harush Yehonatan:

"We say two things. We have to work for all classes of society. When we go out to protest, we do not protest only for the Mizrahim, but also factory workers, all workers. When we take to the streets we protest for everyone, for society as a whole. We are universal and democratic, but we also demand recognition of our culture, the Mizrahi culture, in order to tell our story, to read our books and poetry, to listen to our music. We work for recognition and social change. These are the causes that founded the Keshet" [Harush Yehonatan, author's interview, 2016].

Following this discourse, they mainly focused on land distribution and the role of education, as the two major issues through which the dominant Ashkenazi class has structured Israeli society by increasing asymmetries and inequalities between Ashkenazim and Mizrahim and in general between Ashkenazim and the other most marginalized communities. As the coalition has called for a more egalitarian land allocation system and a reformulation of public housing policies, they have demanded cultural and educational recognition for the Mizrahim as legitimate actors in Israeli history. ${ }^{8}$

7 Nowadays, these disadvantaged neighbourhoods are also populated by labour migrants and African refugees since rental prices are lower than in other parts of the big cities, such as in south Tel Aviv, where they are concentrated in the area around the central bus station.

8 This point is at the core of the Mizrahi struggle. In fact, the historical and cultural representation of the Mizrahim has always consisted of negative images of primitive, backward people, while Mizrahi history has been mostly excluded from official textbooks and programmes at different levels of education in Israel. 
On the other hand, they have had to face the religious trend linking ultraZionism with ultra-Orthodoxy that has promoted the rise of more recent Mizrahi parties. There is the one called Shas (abbreviation of Shomrei Sfarad, in Hebrew) that has fought to save Mizrahi cultural and religious tradition, but has taken a strong Zionist perspective and, consequently, an anti-Arab and anti-Palestinian approach (Pappé 2014: 192-196). It has therefore not been easy for activists of the Mizrahi Democratic Rainbow Coalition to continue their universalism and, at the same time, particularism, in looking for feasible common causes with the Palestinians, who represent the second non-dominant, marginalized community in Israel.

Another significant example of a Mizrahi grassroots organisation has been developed by Mizrahi feminist activists from Achoti (Sister) - for women in Israel since the late 1990s to deal with the meaning of sisterhood in multiethnic and multicultural societies. They have focused on the principles of "feminism of colour" to create an alternative way of looking at and questioning Israeli society. ${ }^{9}$ They have promoted deep connections and common projects among women from different socio-political backgrounds, including Mizrahi Jews, Palestinians, Bedouins, Ethiopians, Russians and, more recently, African refugees from Eritrea and Sudan (Daniele 2014: 68-70). This standpoint has been the main feature of this organisation to unite similar struggles led by the poorest, most underrepresented communities in Israel. As explained by the director, Shula Keshet:

"We are making connections not only with Palestinians, but also Mizrahim, Ethiopians and asylum seekers, because we believe that underprivileged communities have to understand that they have a mutual interest in struggling together, for everything, for ending the occupation, for ending gentrification, for demanding justice and equal distribution of funds. This is what we are doing. Our agenda is multi-ethnic, multi-national and feminist. We also hear from the grassroots, what people need and not only connections with the politicians. Through these meetings people understand the struggle of other similar underprivileged communities. If it is not coming from the people, it will not happen" [Keshet, author's interview, 2016].

9 This expression is closely connected with the so-called "black feminism" that started questioning the mainstream feminist theory led by white women mostly based in Europe and the United States in the early 1980s. One of the main approaches adopted by black feminists has been called "intersectionality" (Crenshaw 1989), meaning interaction between a number of narrative identities (including class, ethnicity, race, gender and nationality) at the base of social, economic, political and cultural discriminations and oppression. From this perspective, if we are to fully understand the conditions of marginalized players, it is necessary to consider multiple narrative identities and their interrelations with systems of power and privileges. 
As a result, they have called into question the asymmetric relations between Ashkenazim and Mizrahim that have also been at the foundation of the Israeli feminist and women's movement. ${ }^{10}$ Mizrahi women have protested against the Ashkenazi hegemony, which has existed not only at a theoretical level but in everyday situations such as work, careers and welfare services. The Mizrahi feminist outlook has stressed the importance to address the needs of women who live in marginalized socio-economic conditions and suffer both individual oppression because of their gender and collective oppression for belonging to underprivileged communities.

\section{MULTIPLE VOICES, BUT A COMMON STRUGGLE: ETHNIC AND CLASS INTERACTIONS}

As demonstrated throughout these historical initiatives of Mizrahi grassroots activism in the Jewish state in the last 40 years (even though some were shortlived), it is evident that their role has been crucial in Israeli politics and society. Because they have been segregated in many sectors, such as education and the political and economic systems, the Mizrahi people have been oppressed and exploited by the ruling Ashkenazi establishment. The Mizrahi Jews' inferior status has been a constant feature of everyday life and has caused the Mizrahim to disconnect themselves from their own history and culture and consider themselves falsely integrated into Israeli society. After their arrival in the early 1950s, most Mizrahi people decided to "de-Arab" themselves in order to become full members of a society dominated by Ashkenazi Jews (Pappé 2014: 179-186).

On such a controversial topic, it is significant to underscore that the Israeli Left has generally been considered the main expression of the "white Ashkenazi middle class" owning power and privileges denied to the Mizrahi people. In many cases, this starts with the choice not to join the army and its relevant consequences, ${ }^{11}$ while the Mizrahim have had to follow a stricter, more traditional pathway to be assimilated into Israeli society [Madar, author's interview, 2016]. As a reaction, it is not surprising that the majority of the

10 For further information, see Henriette Dahan-Kalev (2001); Giulia Daniele (2014); Smadar Lavie (2011); Pnina Motzafi-Haller (2001).

11 Military service in Israel is mandatory for all Israeli citizens over the age of 18 and lasts three years for men and two for women. The only exceptions regard Palestinian citizens of Israel and ultra-orthodox Jews (yeshiva students). Refusal to join the army is still a controversial issue in Israeli society and is closely related to socio-economic and ethnic backgrounds. In fact, it is no coincidence that the majority of Mizrahi Jews, Ethiopian Jews and Russians serve in the army and are usually sent to the frontline in the occupied Palestinian territories [Mehager, author's interview, 2016]. As part of marginalized communities, they need to join the army to be fully considered citizens of the state of Israel, even though in reality they continue to undergo subordination, discrimination and racism. 
Mizrahi population has found its political home in the right-wing coalition led by the Likud, considered the natural representative of the most frustrated and marginalized communities. As explained in the words of Tom Mehager, a Mizrahi activist working in the Palestinian-run legal centre in Israel, AdalahThe Legal Center for Arab Minority Rights in Israel:

"The Mizrahi people see the Left as Ashkenazi. They see academia as Ashkenazi, because only when the Mizrahim are part of the leadership in the Left will people maybe speak differently about these issues. The Left talks about stopping the occupation, but at the same time it says nothing about privileges, the Mizrahim or Ethiopians. You cannot be colour-blind. It was the Left that committed crimes against the Mizrahi people, and when in the beginning someone told you that you'd be at the bottom, you had to pull yourself up somehow. The Right helps you to pull yourself up with nationalistic values. It's very easy for the Left to adopt universal values, when they already have everything, all the privileges. The people in lower ranks need somehow to have their own identity, so their identity becomes more nationalistic or religious or both. In many ways the Mizrahi people's massive support of the Right is part of their situation; it is the resource they have" [Mehager, author's interview, 2016].

The reasons why the great majority of Mizrahim have neither supported nor voted for the Left have been highly disputed in the internal debates of grassroots political activists, both Mizrahi and Ashkenazi. According to most of my interviewees, one of the main causes has been the fact that, in addition to the mainstream Zionist left-wing led by the Labour Party, other leftist parties such as Meretz ${ }^{12}$ and Hadash ${ }^{13}$ have also chosen to ignore the socio-economic gap between the centre and peripheries, namely the ongoing

12 Meretz is a Zionist left-wing party founded in the early 1990s that became the third largest party in the 1992 elections. It has stood for "human and civil rights, a social-democratic economic policy, vehement opposition to continuing the occupation, and political moderation" (for more information, see the English version of their website: < http://meretz.org.il/english/>, last access in February 2019). In spite of such a statement, most of the Mizrahi activists I interviewed during my fieldwork criticised this political initiative for continuing to ignore the internal asymmetry between Ashkenazim and Mizrahim.

13 Hadash is an historic example of a joint Jewish-Palestinian leftist movement in Israel. Although they have aimed at creating "a political alternative to the government's policy of occupation and exploitation" and struggling for "workers' rights, social justice, opposition to privatization, democratic liberties and human rights, equality for the Arab minority, ethnic groups, women, the protection of the environment and the disarmament of mass destruction weapons" (to get more details, see the English version of their website, <http://hadash.org.il/english/ >, last access in February 2019), the majority of Mizrahi interviewees expressed their criticism and perplexity at the lack of a clear position towards the ongoing disparities between Ashkenazim and Mizrahim in Hadash's political agenda. 
asymmetries between the Ashkenazim and Mizrahim. In the wider panorama of the Left in Israel, the current discourse has completely ignored the main issues of egalitarian political and cultural representation, fair economics, a democratic education system and fair division of land.

This scenario is not new. It goes back to 1977, a key year in which the Israeli political arena completely changed. For the first time, the Likud Party won the elections thanks to major support from the Mizrahi people. The Mizrahim used to vote for the Mapai, the Labour Party's predecessor, but since then they have started regarding the left-wing as based on the Ashkenazi hegemony and the achievement of its own interests. Furthermore, as a result of their exclusion from Israeli society, they have started taking Zionist nationalist positions that have allowed them to be much more accepted and integrated. Consequently, the right-wing has become a "natural home" for the Mizrahi people, even if it has not actually provided alternative solutions for changing the status quo.

Throughout its narrative, the Israeli Zionist Left has consciously avoided any in-depth discussion of the historical asymmetric relationship or significant disparities between Ashkenazim and Mizrahim. Although they have based their actions and struggles on the Israeli military occupation of the Palestinian territories, at the same time, they have continued to keep their privileges and distance from the repressive everyday life experienced by the most marginalized communities in Israel itself.

While the majority of Ashkenazi leftists have consistently considered the Israeli military occupation to be one of the most terrible violations of human rights, they have been not able to understand or question the complex interconnections between different forms of violation of human rights that exist in the land of Palestine/Israel. This complexity is essential in connecting heterogeneous social and political struggles that can be related to different levels and issues, as explained by Sigal Harush Yehonatan:

"If you care about human life, if you care about justice and the complexity of such things, you have to think widely, not only focus on one issue. For me if you are leftist, it should come from inside you. You have to see a universal struggle, you have to see class struggles, you have to see other injustices. In Israel, the Left is very arrogant. It is a bourgeois Left, not a true Left. They tell you that they are against the occupation, that it is not human what Israel is doing towards Palestinians, but they are racists. The real Mizrahi people see that and do not want to be like them. They do not want to belong to them, so they move to the Right. For this reason, the Right in Israel is more democratic. The Likud is more democratic than Labour and Meretz, since there are many Mizrahi members in the Likud party and as members of the Knesset. It's an enigma. It's true, it's a rightwing party but it's more democratic, and the Mizrahi people therefore look 
at it as their home. The Left has made a lot of mistakes, and is still making a lot of mistakes" [Harush Yehonatan, author's interview, 2016].

The vast majority of Mizrahim I met during my fieldwork, both activists and common people, strongly criticised the mainstream Ashkenazi left-wing and its failure to deal with asymmetries and inequalities in the state of Israel. Their discourse is also relevant in another current widespread debate in the country, namely the separation - instead of mutual collaboration - between the so-called "political activism" and "social activism." In Israel's particular case, political activism is mainly associated with the struggle against the Israeli military occupation and the Palestinian people's right to self-determination. Social activism has to do with internal protests, especially on issues such as public housing, gentrification and expropriation of homes and land.

This distinction also involves a class-based perspective, in that while political activism has been mostly led by the Ashkenazi middle class, social struggles have been largely conducted by Mizrahi lower classes at the bottom of the social hierarchy, principally represented by Mizrahi single mothers (Em Chadorit, in Hebrew). In this framework, it has become necessary to rethink these socio-political disconnections and, as already underlined, to understand the inextricable relationships among them. These two forms of struggle need to be combined in order to find a political strategy that can strive to end the military occupation and work towards a fair solution of the conflict with the Palestinians. But it must also work towards social reforms aimed at restructuring social policies on education, health care and public housing.

This reality has also resulted in a deeper analysis of people's identity and belonging to their own communities. In the case of political activism and Ashkenazi left-wing activists, self-definition as "Israelis" and not as "Ashkenazim" has been the most common one. The Mizrahi social activists" own perceptions of their struggles have been closely related to their self-definition as "Mizrahim" and not as "Israelis." The Mizrahi identity has become part of the social experience of people from the margins, unable to fully achieve their fundamental rights or gain access to common resources. Mizrahi forms of grassroots activism have also been founded on the ethnic issue due to the racial discriminations that they have suffered. At the same time, they have taken two attitudes to their fight, one from outside when negotiating with the Ashkenazi ruling class, and the other when talking about the main challenges inside their own community [Leibner, author's interview, 2016]. As expressed by the sociologist Meir Amor:

"The Ashkenazim and Mizrahim are a reality that was created in Israel, by government policies, not because of their places of origin, as the Ashkenazi and Mizrahi people were born in Israel. It is a social construction 
that was created in this country. It is a question of the mind, but it is also a question of the body. They have completely different stories, as both groups are Israelis but at the same time they have different perspectives and challenges and are looking for different solutions" [Amor, author's interview, 2016].

These interconnections between diverse forms of activism, narrative identities and self-representations have shown the urgent need to link social and political commitments in Israeli society, so that processes of change not only from within, but also in the context of the Israeli-Palestinian conflict, can alter the status quo. Nevertheless, this standpoint has continued to be very controversial regarding the complex relationships the Mizrahi people are still experiencing in the current Israeli system led by the dominant Ashkenazim. On the one hand, the Mizrahim have been oppressed, but, on the other hand, they have fought to be accepted as full members of this asymmetric system and to make their Mizrahiness a title required to feel like regular citizens. ${ }^{14}$

Indeed, these ongoing internal divisions in Israeli Jewish society have reaffirmed tensions and clashes between a powerful group that controls everything and another that has been fighting for its rights for too long [Abergel, author's interview, 2016]. In other words, the status quo has been described as a struggle with a group that does not want to lose its privileges or position of power and is causing ethnic cleansing within Israel itself [Hatuka, author's interview, 2016].

\section{CONCLUSION}

Although the Mizrahi struggle has been always a contentious topic at the core of Israeli public debate, especially at grassroots level, it has been questioned more and more in recent years. In particular, a few recent initiatives have

14 There is not a single definition of Mizrahi narrative identities, which are various, depending on their countries of origin, but also on different generations (as the third and fourth generations of young Mizrahim differ significantly from the first and second generations, who had just arrived in the new state). Mizrahiness is based on ethnic, cultural and class narrative identities that are strongly interconnected in defining differences, asymmetries and privileges within Israeli society. As a matter of fact, this term has been used not only to describe the ongoing socio-economic and cultural oppression experienced by the Mizrahi community, but also to define the way in which Mizrahi people have wanted to be integrated into Israeli society, distancing themselves from their historical, cultural and geographic origins or, on the contrary, to stress and to recognise their origins. Moreover, it can represent a way of thinking as well as the foundation of the Mizrahi struggle. To examine the heterogeneity of narrative identities regarding the Mizrahi people, their linkages and their diversities in more depth, see the work of the most recognised Mizrahi scholars such as Sami Shalom Chetrit, Ella Shoahat, Yehouda Shenhav and Smadar Lavie. 
provided the opportunity to talk openly about the Mizrahi issue, starting with the revival of the disappearance of more than 1,000 Yemenite children in the nascent state of Israel and the establishment of the Biton Committee - formally known as the Committee for the Empowerment of the Culture of Sephardic and Eastern Jewry in the Educational System.

On the subject of the missing children, a new organisation called Amram, ${ }^{15}$ founded by third generation Mizrahim to raise awareness of the kidnapping of Yemenite children in the 1950s, has been able to get media coverage on a tragic, relatively unknown event in Israeli history. These activists called into question the government panel that investigated the disappearance without producing any conclusion as to the responsibility of state institutions. They decided to use DNA testing, to collect as many witness statements as possible from Yemenite family members whose children had disappeared in those years, and to publish their interviews and results online. Even though the official version is that no-one knows what really happened, a few voices from Netanyahu's party and government have recently started to show solidarity with this cause [Pessah, author's interview, 2016].

Around the same time, the Ministry of Education set up the Biton Committee to increase recognition of Mizrahi culture and history and include them in curricula at schools and universities. Instead of highlighting the need to accept the legitimacy of Mizrahi culture in Israel, the committee's July 2016 recommendations and the subsequent opinions expressed mainly by Miri Regev, Minister of Culture and Sport, who is of Mizrahi origin, have generated a factional, populistic debate (Mualem 2016). Though with unresolved question marks and controversies, in both cases the Mizrahi issue has started being discussed by institutions and the public.

Overall, in the majority of cases, Mizrahi grassroots activism has not been able to make much progress for a number of reasons. One is the fact that any international news coming out of Israel is mainly connected to the IsraeliPalestinian conflict. Further reasons are related to the strong desire of the majority of the Mizrahi people to be part of the Israeli mainstream, and to the state's bureaucratic logic (Lavie 2014: 72-84). Nonetheless, third-generation Mizrahim are continuing the struggle, though using alternative tools and practices. As they want to make a difference, they do not look to the future or the past, but only consider direct examples from their own families regarding the oppression suffered by their parents and grandparents for more than 60 years [Hatuka, author's interview, 2016]. In spite of their different political perspectives and forms of struggle, the older generation is supporting the younger, as emphasised by Reuven Abergel referring to the Ars Poetica initiative

15 For more details, see their Facebook page (mainly in Hebrew): < https://www.facebook.com/ Amram-187986401534068/> (last access in February 2019). 
that was founded by a group of young Mizrahi poets as a sort of Mizrahi cultural renaissance: ${ }^{16}$

"Our talented younger generations know that there are such centres of power. They confront these centres of power, and this confrontation is done through art, poetry, writing, song. These people do not use Molotov cocktails, as we did, but they fight with words that undermine the hegemony. We recognise that there is a change in the younger generations. It's very encouraging as they are still attacking the power structure. From my age I can see the weakening power of the Ashkenazi. They are unable to withstand the fight. While they may have legal excuses to stop us, like arrests for violence, they are powerless against words. They cannot bring our poetry and words to court and charge us with drawing or speaking out" [Abergel, author's interview, 2016].

As I have attempted to point out throughout this paper, it would be unfair to portray the Mizrahi people and history only as a story of victimhood and forget a flourishing grassroots social and political activism that has played a crucial role in fighting against subordination and abuses since the 1950s. Listening to and reporting a variety of Mizrahi voices and perspectives implies an in-depth analysis of the close connection between ethnic, political and class narrative identities that have been used within the heterogeneity of the Israeli Jewish community to engender different forms of discrimination and marginalization.

At present, another challenging political initiative called Mizrahit Meshutefet has been undertaken by an activist alliance of Mizrahim and Palestinian citizens of Israel to provide an alternative to the general panorama in Israel after the last election in 2015. As demonstrated throughout the analysis conducted here, it is not a new idea, as Mizrahi activists, starting with the Black Panthers, have been involved in such projects for decades. It is also necessary to underline that internal inequality in Israel is increasing. The Mizrahi community has not constituted a social block, but has been composed of radically divergent political views and social positions. On the other hand, a serious analysis of Israeli society is required to show how the Mizrahim and Palestinians together represent the majority that could change the status quo in which a minority continues to rule over the so-called "others." The original message of this group is founded on the idea that oppressed people have to

16 The name is a combination of Horace's Ars Poetica (Art of Poetry) and the Israeli slang word 'ars', which means 'pimp' in Arabic and is also used as a derogatory term for Mizrahi men. Led by Adi Keissar, a Yemeni Jew, the group was founded in 2013. Its aim is to share the most unknown aspects of Mizrahi culture and demonstrate the domination of the Ashkenazi perspective in the Israeli cultural panorama. 
unite and have to share common fights to establish a link between social and political issues. As one of the founders, Revital Madar, explained to me:

"We wanted to make more room for the Mizrahi Left voice. Generally speaking, Mizrahi people are always perceived as right-wing. We felt that the Zionist Left, the White Left in Israel, was failing again and again because of its ignorance of other groups. During the history of the state of Israel there have been different examples of cooperation between Mizrahi and Arab people who were attacked by the state. Each time there is cooperation between Mizrahim and Palestinians the state is terrified. It happened in Wadi Salim and afterwards with the Panterim. We were in the news just a few weeks ago. We are still trying to understand how it might work. We really wanted to support the Joint List and we had a meeting with them. We do not want to be a burden on them but it is really hard because they are attacked daily" [Madar, author's interview, 2016]. ${ }^{17}$

Although this project of bridging and bringing marginalized communities together has been intellectually defined as brave, it is still politically rather weak. In fact, the idea of making contacts with the other side and working on common issues - such as the unresolved question of unfair distribution of land and inhumane conditions of imprisonment in which the majority of detainees are Palestinians and Mizrahim [Madar, author's interview, 2016] - has been only supported by a minority within these oppressed and discriminated groups, i.e. a minority within a minority. Rather, paradoxically, in the last decades right-wing narratives have increased both institutionally and at the grassroots level in such minority contexts, overtaking historic leftwing claims of equality.

Even so, it is undeniable that a reinforced Mizrahi discourse, with the support of other underrepresented communities such as the Palestinian citizens of Israel and African refugees, has attempted to suggest a new agenda combining different struggles conducted by groups usually excluded from the public eye and the dominant mainstream system. If a more influential and critical perspective of the existing hierarchy seems to come forward, social and political struggles will need to be strictly interconnected to face the major inequalities that have been created throughout history in the land of Palestine/ Israel.

17 The Joint List was formed at the time of the 2015 elections and consisted of the four leading Palestinian parties in Israel, namely Hadash, the United Arab List, Balad and Ta'al. In March 2015, they achieved a significant result as the third largest party in the Knesset. 


\section{REFERENCES}

ABU, Ofir, 2011, "Citizenship, identity, and ethnic mobilisation in Israel: the Mizrahi democratic rainbow - between universalism and particularism", in Guy Ben-Porat and Bryan S. Turner (eds.), The Contradictions of Israeli Citizenship: Land, Religion and State. London and New York, Routledge, $111-134$.

BERNSTEIN, Deborah, and Shlomo SWIRSKI, 1982, "The rapid economic development of Israel and the emergence of the ethnic division of labour", British Journal of Sociology, 33 : 64-85.

BHOPAL, Kalwant, and Ross DEUCHAR (eds.), 2016, Researching Marginalized Groups. London and New York, Routledge.

CHETRIT, Sami S., 2009, Intra-Jewish Conflict in Israel: White Jews, Black Jews. London and New York, Routledge.

COHEN, Shalom, and Kokhavi SHEMESH, 1976, "The origin and development of the Israeli Black Panther movement”, MERIP Reports, 49: 19-22.

CRENSHAW, Kimberle, 1989, "Demarginalizing the intersection of race and sex: a black feminist critique of antidiscrimination doctrine, feminist theory and antiracist politics", University of Chicago Legal Forum, 1989 (1): 138-167.

DAHAN-KALEV, Henrietta, 2001, "Tensions in Israeli feminism: the Mizrahi-Ashkenazi rift", Women's Studies International Forum, 24: 1-16.

DANIELE, Giulia, 2014, Women, Reconciliation and the Israeli-Palestinian Conflict: The Road Not Yet Taken. London and New York, Routledge.

GALATY, John G., 1982, “Being 'Maasai', being 'People-of-Cattle': ethnic shifters in East Africa", American Ethnologist, 9 (1): 1-20.

GHANEM, As'ad, 2010, Ethnic Politics in Israel: The Margins and the Ashkenazi Center. London and New York, Routledge.

GREENSTEIN, Ran, 2014, Zionism and Its Discontents: A Century of Radical Dissent in Israel/ Palestine. London, Pluto Press.

HASSON, Shlomo, 1993, Urban Social Movements in Jerusalem: The Protest of the Second Generation. Albany, State University of New York Press.

HERZFELD, Michael, 1997, Cultural Intimacy: Social Poetics and the Real Life of States, Societies, and Institutions. London and New York, Routledge.

LAVIE, Smadar, 2011, "Mizrahi feminism and the question of Palestine", Journal of Middle East Women's Studies, 7 (2): 56-88.

LAVIE, Smadar, 2014, Wrapped in the Flag of Israel: Mizrahi Single Mothers and Bureaucratic Torture. New York and Oxford, Berghahn.

LEIBNER, Gerardo, 2015, "HaTikva Encampment, 2011 : the ambiguous agency of the marginalized”, Current Anthropology, 56 (11): 159-168.

MOTZAFI-HALler, Pnina, 2001, "Scholarship, identity, and power: Mizrahi women in Israel”, Signs, 26 (3): 697-734.

MUALEM, Mazal, 2016, “Mizrahi Heritage Committee’s quiet revolution”, Al-Monitor, July 13.

PAPPÉ, Ilan, 2014, The Idea of Israel. London and New York, Verso.

SHOHAT, Ella, 1988, "Sephardim in Israel: Zionism from the standpoint of its Jewish victims", Social Text, 19-20: 1-35.

SHOHAT, Ella, 2006, Taboo Memories, Diasporic Voices. Durham, NC, Duke University Press. 
SMITH, Linda T., 1999, Decolonizing Methodologies: Research and Indigenous Peoples. London and New York, Zed Books.

SWIRSKI, Shlomo, 1989, Israel: The Oriental Majority. London and New York, Zed Books.

TZFADIA, Erez, and Oren YIFTACHEL, 2003, "Between urban and national: political mobilisation among Mizrahim in Israel's 'development towns', Cities, 21 (1): 41-55.

VERACINI, Lorenzo, 2006, Israel and Settler Society. London, Pluto Press.

WOLFE, Patrick, 1999, Settler Colonialism and the Transformation of Anthropology. London, Cassell.

YIFTACHEL, Oren, 2000, "Social control, urban planning and ethno-class relations: Mizrahi Jews in Israel's 'development towns", International Journal of Urban and Regional Research, 24 (2): 418-438.

Receção da versão original / Original version

$2016 / 12 / 12$

Receção da versão revista / Revised version

$2018 / 02 / 23$

Aceitação / Accepted

$2018 / 07 / 25$ 